\title{
Kultura Lean Management w polskich szkołach wyższych (wyniki badań pilotażowych)
}

\begin{abstract}
STRESZCZENIE: Brak powiązania wdrażania Lean Management ze zmianą kultury organizacyjnej obniża trwałość efektów restrukturyzacji oraz nie przyczynia się do doskonalenia procesów w szkole wyższej w długiej perspektywie. W artykule przestawiono wyniki badań, których celem była identyfikacja cech kultury organizacyjnej szkół wyższych w kontekście wdrażania koncepcji LM oraz określenie zakresu niezbędnych zmian. W badaniach zastosowano metody analizy literatury przedmiotu, badań ankietowych (przeprowadzonych w szkołach wyższych z wykorzystaniem wymiarów Kultury Lean opisanych w książce The Toyota Way Likerta), wywiadów z pracownikami oraz doświadczenia własne autorki. Wyniki badań ankietowych potwierdzają postawioną hipotezę, że kultura organizacyjna badanych szkół stanowi barierę we wdrażaniu Lean Management. W wyniku przeprowadzonej analizy regresji można stwierdzić, że zmiennymi, które w istotny sposób różnicują wyniki ankiety są: rodzaj szkoły, funkcja oraz staż pracy. Wywiady wskazują, że zmiana techniczno-organizacyjna przebiega równolegle i jest zintegrowana ze zmianą społeczną, tylko wtedy kiedy projekty są wdrażane z przyjęciem podejścia oddolnego. Wyniki badania jednoznacznie wskazują, że zastosowanie paradygmatu funkcjonalistycznego w badaniu kultury organizacyjnej uczelni jest niewystarczające, gdyż nie pozwala dostrzec w pełni innych składników i obszarów Kultury Lean. Dlatego postuluje się rozszerzenie perspektywy badawczej o podejście humanistyczne oparte na paradygmacie interpretatywnym.
\end{abstract}

SŁOWA KLUCZOWE: kultura organizacyjna, kultura Lean Management, uniwersytet, ocena kultury Lean

\section{Wstęp}

Uniwersytet jest jedną z najstarszych i jednocześnie najbardziej złożonych organizacji stworzonych przez człowieka, której celem jest realizacja często sprzecznych celów w zakresie badań, kształcenia i wpływu na społeczeństwo. Obecnie uniwersytet jest 
organizacją pełną napięć (Geppert i Hollinshead 2017), „zawieszoną” pomiędzy tradycją a nowoczesnością (Leja 2013; Kwiek 2015; Antonowicz 2015; Sułkowski 2016). Część badaczy uważa, że w globalizującym się otoczeniu ekonomicznym, kulturowym i społecznym misja szkoły wyższej jako instytucji służącej sprawie wychowania i kształtowania narodu w celu umacniania państwa wyczerpuje się (Kwiek 2001). Zerwanie trwałych związków wiedzy i władzy powoduje zmianę natury wiedzy oraz procesu jej tworzenia, gromadzenia i przekazywania. Wiedza staje się przedmiotem komercjalizacji - produktem/usługą - głównie prywatną - dostarczaną na zasadach konkurencyjnych w warunkach quasi-rynku. Uniwersytety na całym świecie zmagają się z wieloma wyzwaniami: zmniejszaniem funduszy publicznych na finansowanie; zmieniającymi się wymaganiami odbiorców (studentów, biznesu, rządu i innych); intensywnym rozwojem nowych technologii, które zasadniczo zmieniają sposoby kształcenia, prowadzenia badań oraz kształtowania relacji z otoczeniem (m.in. sieciowanie działań); skupieniem się na skuteczności i efektywności działania („value for money”); presją na doskonałość w kształceniu i badaniach; kładzeniem nacisku na wzmacnianie tzw. wpływu społecznego (social impact) (Maciąg 2011: 15). Wymienione powyżej czynniki dramatycznie i gwaltownie zmieniają kontekst wewnętrzny i zewnętrzny zarządzania szkołą wyższą.

Na fali New Public Management wdraża się w uczelniach pochodzące z przedsiębiorstw produkcyjnych procesowe koncepcje zarządzania (Maciąg 2016a), w tym Lean Management (Emiliani 2005; Yorkstone 2016; Francis, Krehbiel i Balzer 2017), Lean Higher Education (Balzer 2010), Lean University (Emiliani 2015). Koncepcja Lean Higher Education (Balzer 2010) jest obecnie jednym z ważnych wątków podejmowanych w procesie reformowania szkół wyższych o czym świadczą coraz liczniejsze przykłady wdrożeń na całym świecie (np. sieć LeanHE) (http:// www.leanhehub.ac.uk/). Zakłada się, że Lean Management w odmiennych w swej istocie organizacjach, jakimi są uniwersytety, przyniesie takie same sukcesy jak w organizacjach biznesowych. Badania prowadzone w organizacjach publicznych wskazują, że Lean przynosi pozytywne efekty w systemie organizacyjno-technicznym, podaje się jednak w wątpliwość ich trwałość (Radnor i Bucci 2011). Wynikać to może z faktu, że uczelnia często wprowadza pseudozmiany, aby uczynić się bardziej atrakcyjną dla interesariuszy (Alvesson 2013). Jej bezwład, inercję oraz skupienie na samoodtwarzaniu wyjaśnia się izomorfizmem przymusowym (Santana i in. 2010), konfliktem wartości (Lenartowicz 2016) czy silną tożsamością organizacyjną (Sułkowski 2016).

Opór oraz brak trwałości zmian wyjaśnia się tym, że zbyt mało uwagi przywiązuje się do rozwoju kultury organizacyjnej - kultury Lean Management (Francis, Krehbiel i Balzer 2017). Brak powiązania wdrażania Lean Management ze zmianą kultury organizacyjnej obniża trwałość efektów restrukturyzacji oraz nie przyczynia 
się do doskonalenia procesów w szkole w długiej perspektywie (Radnor i in. 2006). Przeprowadzona analiza literatury przedmiotu stała się przyczynkiem do podjęcia badań pilotażowych nad kulturą organizacyjną szkół wyższych. Celem badania była identyfikacja cech kultury organizacyjnej szkół wyższych w kontekście wdrażania koncepcji LM oraz określenie zakresu niezbędnych zmian. W badaniu wykorzystano metody analizy literatury przedmiotu, badań ankietowych przeprowadzonych w pięciu polskich szkołach wyższych (badania pilotażowe), wywiadów z pracownikami uczestniczącymi w projekcie restrukturyzacji procesowej z wykorzystaniem metodyki Lean Management oraz doświadczenia własne autorki. Opracowanie jest głosem w szerszej dyskusji na temat możliwości wdrażania nowoczesnych biznesowych koncepcji zarządzania w szkołach wyższych oraz zmianach jakie mogą one wywołać w kulturze organizacyjnej.

\section{Kultura Lean Management w szkołach wyższych}

Podejmując próbę zdefiniowania pojęcia kultury Lean Management (Kultury Lean) w odniesieniu do szkół wyższych, rozpoczęto od zdefiniowania pojęcia kultury organizacyjnej szkół wyższych, następnie wskazano na najważniejsze zasady oraz podejścia do definiowania Kultury Lean Management.

W literaturze przedmiotu można odnaleźć wiele definicji kultury organizacyjnej. Do klasycznych zalicza się definicje Jacquesa, Sheina czy Mintzberga (Wolniak 2012: 93). Sułkowski kulturę organizacyjną szkoły wyższej definiuje poprzez zestaw następujących składników (Sułkowski 2017: 284):

- wartości kulturowe, podstawowe założenia, normy społeczne i organizacyjne rdzeniem kultury są wartości lub podstawowe założenia, które określają fundamenty organizacji (jej tożsamość, rolę człowieka i stosunek do otoczenia), to na nich oparte są normy społeczne określające zachowania członków organizacji (nakazy i zakazy);

- sposoby komunikowania, opowieści, narracje, mity - są to ustne, nieformalne przekazywane przez pracowników opisy rzeczywistych lub wzbogaconych fantazją zdarzeń z historii uczelni;

- symbole - znaki stanowiące odzwierciedlenie wartości kulturowych np. nazwa uczelni i jej logo, marka, emblematy, sztandary itp.;

- metafory - odzwierciedlają istotę uczelni, pokazują, w jaki sposób jest ona widziana przez interesariuszy (pracowników, studentów, otoczenie);

- rytuały i rutyny - utrwalone sposoby prawidłowego działania w szkole wyższej;

- zwyczaje i obyczaje - powtarzalne i spetryfikowane praktyki społeczne;

- artefakty - widoczne przejawy funkcjonowania kultury organizacyjnej, wyróżniamy wśród nich artefakty fizyczne (np. przestrzeń, budynki, architektura), 
behawioralne (np. gesty, powitania, komunikacja niewerbalne) oraz językowe (np. konwencje językowe, tytułowanie w wypowiedziach);

- subkultury - znajdujące się wewnątrz kultury organizacyjnej grupy społeczne i powstające wokół wartości, które nie są spójne z kulturą całej organizacji;

- stereotypy - wiedza pochodząca z doświadczenia i wykorzystywana w analogicznych sytuacjach związanych z tożsamością, relacjami pracowników, relacjami $\mathrm{z}$ otoczeniem, relacjami ze studentami;

- bohaterowie - ważne postacie, które wywarły znaczący wpływ na organizację i jej kulturę - założyciele, menedżerowie, liderzy, charyzmatyczni pracownicy, ważni interesariusze;

- tabu - temat lub działanie społeczne, które z jednej strony są ukrywane i nieporuszane z drugiej - ważne dla organizacji, uświęcone tradycją.

Wymienione elementy nie są traktowane jako równorzędne i równoznaczne. W literaturze istnieje wiele modeli porządkujących wyznaczniki kultury organizacyjnej z przyjęciem różnych kryteriów. Na przykład:

- podatności na zmianę vide diagram cebuli Hofstede (rdzeń stanowią stałe wartości, otoczkę tzw. praktyki, które mogą ulegać zmianie) (Hofstede 2011: 23);

- poziomu uświadomienia i możliwości badania vide model kultury organizacyjnej Sheina (na kulturę składają się założenia podstawowe/wartości fundamentalne - niewidoczne i najczęściej nieświadome, normy i wartości - częściowo widoczne, częściowo nieświadome, artefakty i twory kulturowe - widoczne, ale często niezrozumiałe, wymagające interpretacji) (Hatch 2002: 214).

Kultura organizacyjna jest nieodłączną częścią każdej aktywności człowieka, która ma znamiona działania zorganizowanego (tj. celowość, trwałość, złożoność oraz organizację). Jest ona wyznaczana przez czynniki zewnętrzne - takie jak religia, ustrój społeczno-gospodarczy, ustrój państwa, rola organizacji w państwie - oraz czynniki wewnętrzne: np. rodzaj działalności (produkcja, handel, usługi), postawa właściciela/zarządzającego, postawa pracowników klientów i innych partnerów organizacji. Początkowo badania nad kulturą organizacyjną związane były przede wszystkim z kulturą narodową, przedmiotem badań w obszarze zarządzania stała się ona dopiero w XX wieku w nurcie human relations (dotyczyły one początkowo klimatu organizacyjnego). Obecnie można mówić o rozwoju nurtu badawczego w zarządzaniu to zarząadzanie kulturą organizacyjną (Sułkowski 2012: 56).

Szczególnym przypadkiem kultury organizacyjnej jest kultura organizacyjna uniwersytetu, której początki sięgają czasów starożytnych (Akademia Platońska) oraz średniowiecznych korporacji studenckich i profesorskich. Tradycyjnie kulturę organizacyjną wyznaczały wartości takie jak relacja mistrz-uczeń, prawda, wiedza, 
autonomia, niezależność, wolność, ponadnarodowość, wspólnotowość (Woźnicki 2000: 59). Można zatem stwierdzić, że z jednej strony powstanie organizacji, jaką jest uniwersytet, jest wynikiem instytucjonalizacji kultury opartej na tradycyjnych wartościach i zasadach akademickich. Z drugiej strony kultura organizacyjna stawała się na przestrzeni wieków narzędziem realizacji misji uniwersytetu. Misja ta na przestrzeni wieków zmieniała się, co znalazło swój wyraz w zmianach kultury organizacyjnej, które podyktowane były różnymi nurtami w rozwoju modeli uniwersytetów (Leja 2013; Sułkowski 2016; Lacatus 2013). Te nurty to:

- nurt humboltowski i napoleoński (wolność akademicka, czysta wiedza, integracja badań i kształcenia);

- nurt newmanowski i amerykański/anglosaski (nacisk na kształcenie, pragmatyczność, autonomia);

- nurt naukowego zarządzania (nurt administracyjny i naukowy, nurt biurokratyczny - kultura biurokratyczna);

- nurt New Public Management (w tym nurt jakościowy - kultura jakości, nurt uniwersytetu przedsiębiorczego - kultura przedsiębiorczości, nurt korporacyjny - kultura korporacyjna)

- nurt good governance (kultura sieciowa, networking).

Początkowo misja uniwersytetu była związana z funkcją społeczną i polityczną uczelni, umacnianiem władzy opartej na wyspecjalizowanej i pogłębionej wiedzy, budowaniem i wzmacnianiem fundamentów państwa narodowego oraz tworzeniem, przechowywaniem i propagowaniem kultury narodowej. Obecnie misja obejmuje nowe pojęcia, początkowo, jak podkreśla Jabłecka, całkowicie obce kulturze debaty akademickiej: efektywność, wydajność, oszczędność, produktywność, rozliczanie się czy wreszcie planowanie strategiczne bądź utrzymanie pozycji strategicznej (Jabłecka 2000: 9).

Mając na uwadze uwarunkowania historyczne oraz kryteria zdolności do tworzenia i zakresu kontroli wdrażania polityki w szkole wyższej, wyróżnić można cztery typy kultury organizacyjnej w szkole wyższej (McNay 2006; Lacatus 2013). Są to: kultura kolegialna, kultura biurokratyczna, kultura korporacyjna oraz kultura przedsiębiorcza (tabela 1).

Tabela Charakterystyka kultur organizacyjnych w szkole wyższej

\begin{tabular}{|c|c|c|c|c|}
\hline $\begin{array}{c}\text { Model } \\
\text { wyznaczniki }\end{array}$ & $\begin{array}{c}\text { Kultura kole- } \\
\text { gialna }\end{array}$ & $\begin{array}{c}\text { Kultura biuro- } \\
\text { kratyczna }\end{array}$ & $\begin{array}{c}\text { Kultura korpo- } \\
\text { racyjna }\end{array}$ & $\begin{array}{c}\text { Kultura przed- } \\
\text { siębiorcza }\end{array}$ \\
\hline $\begin{array}{c}\text { Dominująca } \\
\text { wartość }\end{array}$ & Wolność & Prawo & Lojalność & Kompetencje \\
\hline $\begin{array}{c}\text { Rola władz } \\
\text { centralnych }\end{array}$ & Liberalna & Regulacyjna & Dyrektywna & Wspierająca \\
\hline
\end{tabular}




\begin{tabular}{|c|c|c|c|c|}
\hline $\begin{array}{c}\text { Model } \\
\text { wyznaczniki }\end{array}$ & $\begin{array}{l}\text { Kultura kole- } \\
\text { gialna }\end{array}$ & $\begin{array}{c}\text { Kultura biuro- } \\
\text { kratyczna }\end{array}$ & $\begin{array}{l}\text { Kultura korpo- } \\
\text { racyjna }\end{array}$ & $\begin{array}{l}\text { Kultura przed- } \\
\text { siębiorcza }\end{array}$ \\
\hline $\begin{array}{c}\text { Jednostka } \\
\text { dominująca }\end{array}$ & $\begin{array}{l}\text { Departament } \\
\text { /Katedra } \\
\text { /Stanowisko }\end{array}$ & $\begin{array}{l}\text { Wydział/Komi- } \\
\text { tety }\end{array}$ & $\begin{array}{l}\text { Instytucja/Ze- } \\
\text { społy kadry kie- } \\
\text { rowniczej }\end{array}$ & $\begin{array}{l}\text { Subjednostki } \\
\text { /Zespoły projek- } \\
\text { towe }\end{array}$ \\
\hline $\begin{array}{l}\text { Grupy podej- } \\
\text { mujące decyzje }\end{array}$ & $\begin{array}{l}\text { Sieci grup niefor- } \\
\text { malnych }\end{array}$ & $\begin{array}{l}\text { Komitety/ spo- } \\
\text { tkania informa- } \\
\text { cyjne } \\
\text { /administracyjne }\end{array}$ & $\begin{array}{c}\text { Grupy robocze/ } \\
\text { Zespoły kadry } \\
\text { kierowniczej }\end{array}$ & $\begin{array}{l}\text { Zespoły projek- } \\
\text { towe }\end{array}$ \\
\hline $\begin{array}{c}\text { Styl zarządza- } \\
\text { nia }\end{array}$ & $\begin{array}{c}\text { Oparty na kon- } \\
\text { sensusie }\end{array}$ & $\begin{array}{l}\text { Formalny/ } \\
\text { Racjonalny }\end{array}$ & $\begin{array}{c}\text { Polityczny/ } \\
\text { Taktyczny }\end{array}$ & $\begin{array}{l}\text { Zdecentralizo- } \\
\text { wany }\end{array}$ \\
\hline $\begin{array}{c}\text { Ramy czasowe } \\
\text { działania }\end{array}$ & Długie & Cykliczne & $\begin{array}{l}\text { Krótkie/ Średnio- } \\
\text { terminowe }\end{array}$ & $\begin{array}{l}\text { Natychmiastowe/ } \\
\text { Ultrakrótkie }\end{array}$ \\
\hline $\begin{array}{l}\text { Sposób dopa- } \\
\text { sowania się do } \\
\text { otoczenia }\end{array}$ & Ewolucja & Stabilność & Kryzysy & Turbulentność \\
\hline Natura zmiany & $\begin{array}{c}\text { Organiczna inno- } \\
\text { wacja }\end{array}$ & $\begin{array}{l}\text { Reaktywna ada- } \\
\text { ptacja }\end{array}$ & $\begin{array}{l}\text { Proaktywna } \\
\text { transformacja }\end{array}$ & $\begin{array}{l}\text { Taktyczna ela- } \\
\text { styczność }\end{array}$ \\
\hline $\begin{array}{l}\text { Punkty od- } \\
\text { niesienia ze- } \\
\text { wnętrzne }\end{array}$ & $\begin{array}{l}\text { Środowisko } \\
\text { akademickie }\end{array}$ & $\begin{array}{l}\text { Instytucje regu- } \\
\text { lacyjne }\end{array}$ & $\begin{array}{l}\text { Politycy jako } \\
\text { liderzy opinii }\end{array}$ & $\begin{array}{l}\text { Klienci/ Spon- } \\
\text { sorzy }\end{array}$ \\
\hline $\begin{array}{l}\text { Punkty od- } \\
\text { niesienia we- } \\
\text { wnętrzne }\end{array}$ & $\begin{array}{c}\text { Dyscyplina na- } \\
\text { ukowa }\end{array}$ & Zasady & Plany & $\begin{array}{l}\text { Studenci/ Siły } \\
\text { rynkowe }\end{array}$ \\
\hline $\begin{array}{l}\text { Podstawa ewa- } \\
\text { luacji }\end{array}$ & $\begin{array}{l}\text { Ocena środowi- } \\
\text { skowa (peer) }\end{array}$ & Audyt procedur & $\begin{array}{l}\text { Wskaźniki dzia- } \\
\text { łalności }\end{array}$ & $\begin{array}{c}\text { Ciągłość/ } \\
\text { Powtarzalność } \\
\text { biznesu }\end{array}$ \\
\hline $\begin{array}{l}\text { Status stu- } \\
\text { denta }\end{array}$ & $\begin{array}{l}\text { Uczeń mistrza/ } \\
\text { akademika }\end{array}$ & $\begin{array}{c}\text { Pozycja w staty- } \\
\text { styce }\end{array}$ & $\begin{array}{c}\text { Jednostka zaso- } \\
\text { bów }\end{array}$ & Klient/odbiorca \\
\hline $\begin{array}{l}\text { Rola admini- } \\
\text { stracji - komu } \\
\text { służy... }\end{array}$ & ...społeczności & ...komitetom & $\begin{array}{c}\text {...dyrektorowi } \\
\text { naczelnemu }\end{array}$ & $\begin{array}{l}\text {...klientom ze- } \\
\text { wnętrznym } \\
\text { i wewnętrznym }\end{array}$ \\
\hline
\end{tabular}

Źródło: (Lacatus 2013: 424).

Obserwacja rozwoju współczesnych uniwersytetów pozwala na wskazanie kolejnego wyłaniającego się typu kultury organizacyjnej - kultury sieciowej, w której dominującą wartością będzie współpraca i relacje w mniej lub bardziej formalnych sieciach o charakterze organizacyjnym i ponadorganizacyjnym (np. sieci badawcze, klastry, sieci studentów, sieci edukacyjne). 
Analiza przedstawionych powyżej kultur organizacyjnych wskazuje, że koncepcja Lean Management oraz Kultura Lean najlepiej wpisują się w kulturę przedsiębiorczą uniwersytetu. Lean Management oraz jego zasady ukonstytuowały się w przedsiębiorstwach produkcyjnych, które charakteryzowały się m.in. stałością zatrudnienia, wystandaryzowanymi procesami i procedurami działania. Samo pojęcie Lean w wąskim zakresie w literaturze przedmiotu tłumaczone jest jako wyszczuplanie lub odchudzanie, szerzej jako elastyczność (umiejętność szybkiego dostosowywania się do zmian), sprężystość (szybkość i dynamika reakcji na zmiany) (Czerska 2009: 16) oraz zwinność (agile - oznacza zdolność do przetrwania i rozwijania się w warunkach nie dających się przewidzieć) (Bednarek 2007: 33). W literaturze przedmiotu trudno odnaleźć jedną definicję Lean Management ${ }^{1}$. Lean jest definiowane jako filozofia zarządzania, metoda zarządzania, zbiór technik i narzędzi. Bywa opisywane również jako zmiana kulturowa, przy czym Kultura Lean jest jednocześnie czynnikiem, który wpływa na implementację koncepcji Lean Management, jak również jej efektem (Radnor i in. 2006: 62).

Badacze, opierając się na dorobku z zakresu badań kultury organizacyjnej, podejmują próby definiowania Kultury Lean jako kultury organizacyjnej (można się też spotkać z określeniem „kultura szczupłej organizacji”) (Walentynowicz 2013: 82; Mann 2014: 190). Można tutaj wyróżnić kilka podejść:

- definicje filozoficzne - kultura Lean określa filozofię działania - Lean Thinking, koncentruje się przede wszystkim na oszczędnym działaniu, tzn. poprawianiu sprawności działań poprzez eliminację marnotrawstwa, zminimalizowaniu marnotrawstwa oraz kontrolowaniu przepływu wartości dodanej (Hamrol 2015: 99). Kultura Lean może też być zdefiniowana w szkole wyższej jako stosowana filozofia działania, której esencją jest jakość relacji między ludźmi, wspólne zachowania oraz kultura pracy (Yorkstone 2016);

- definicje enumeratywne, w których określa się i wylicza składniki Kultury Lean. Przykładem jest definicja sformułowana przez Parkes (2017: 64), której zdaniem kulturę tę można zdefiniować na kilku płaszczyznach: (1) jako filozofię działania - Lean Thinking - zasady, postawy, przekonania, wartości, myślenie działanie ukierunkowane na tworzenie wartości i likwidowanie marnotrawstwa zachowań; (2) jako artefakty językowe, behawioralne i fizyczne - mogą być tłumaczone kulturą narodową, dlatego trzeba zwrócić uwagę na to, co wynika bezpośrednio z Lean, a co jest cechą kultury narodowej; (3) jako normy i zasady oraz metody i techniki, narzędzia ich realizacji;

${ }^{1}$ W literaturze przedmiotu operuje się różnymi terminami, które mają definiować koncepcję Lean. Są to: Lean Management, Lean Manufacturing, Lean Enterprise, Lean Office. Wskazują one w jakim obszarze funkcjonowania organizacji stosowane są zasady Lean (Hamrol 2015: 98). Na potrzeby opracowania jako równoważne będą tu stosowane pojęcia Lean Management, Lean Service i Lean Higher Education. 
- definicje normatywne, w których konstruuje się zasady i normy zachowań członków organizacji (techniczne, organizacyjne, społeczne) oraz techniki i narzędzia ich wdrażania; przykładem są zasady Likera - ich autor uważa, że Lean Management stanowi holistyczną koncepcję zarządzania opartą na 14 zasadach wypracowanych przez Toyotę (Liker 2005: 43) i adaptowanych z powiedzeniem również do sektora usług (Liker i Morgan 2006: 5-20). Zasady te skupione są w czterech obszarach - ogólna koncepcja, procesy, ludzie i narzędzia. Ich implementacja pozwala na skuteczne wdrożenie koncepcji Lean w sferze strategicznej i operacyjnej zarządzania organizacją oraz zmianę kultury organizacyjnej w kierunku zaangażowania pracowników i nieustannej poprawy (rys. 1). Innym przykładem podejścia normatywnego są zasady Lean określone jako nieustanne doskonalenie i szacunek dla ludzi (Robinson i Yorkstone 2014: 47);

Rysunek 1 - zasady Lean Management.

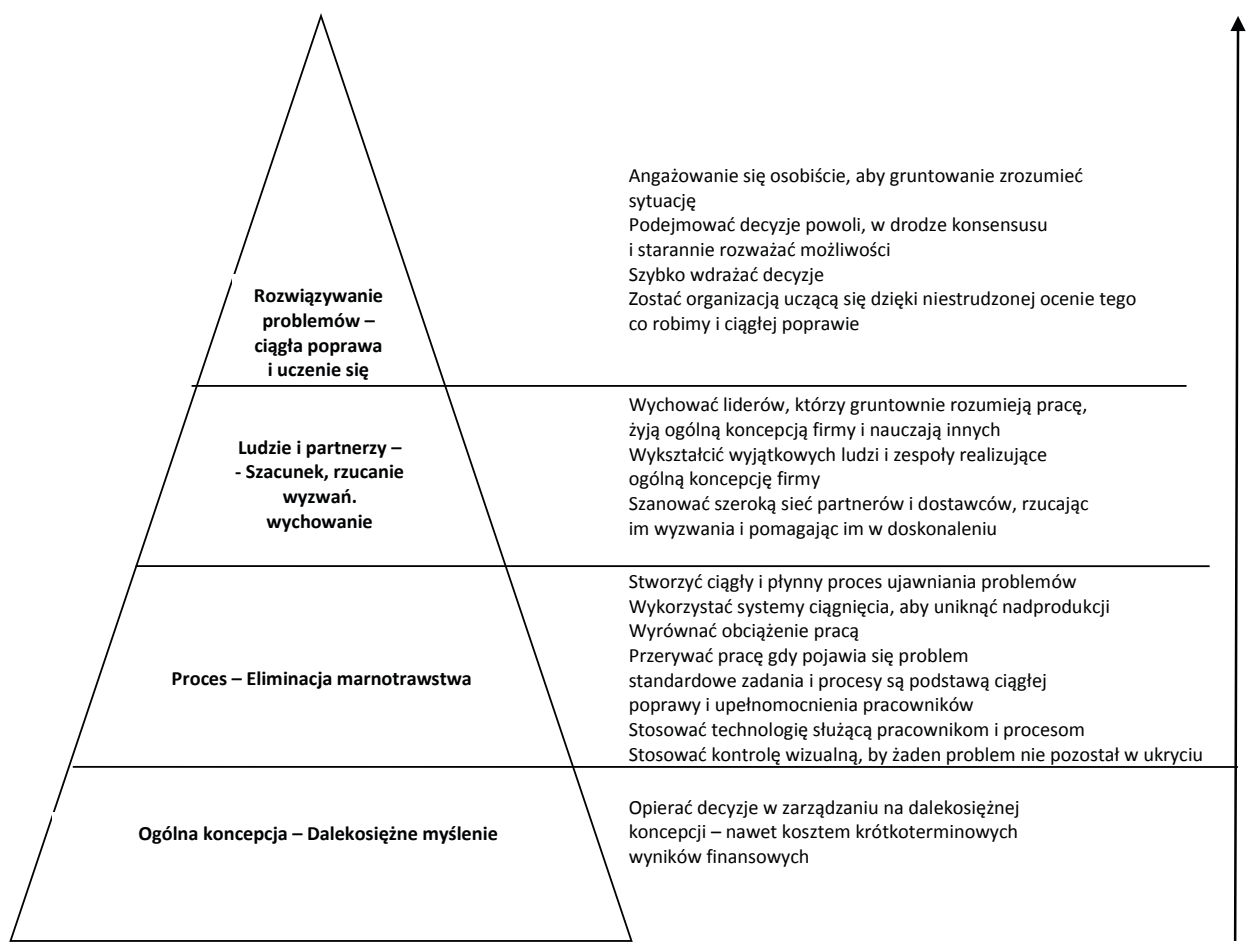

Źródło: Liker 2015; Liker i Morgan 2006. 
- definicje psychologiczne, które podkreślają rolę człowieka w organizacji, jego postawę wobec zmian. Mann wskazuje m.in. na konieczność wygaszania/ zmiany nawyków i zwyczajów pracowników (Mann 2014: 24). Zwraca się też uwagę na motywowanie pracowników w środowisku Lean (Jakubik i in. 2012: 87). Balzer w odniesieniu do uczelni zwraca uwagę na czynniki klimatu organizacyjnego, które wpływają na zachowania i postawy pracowników oraz na to jak rozumieją i widzą swoją rolę w organizacji (Balzer 2010: 96). Wskazuje tutaj na takie czynniki jak: struktura, standardy, odpowiedzialność, uznanie, wsparcie, zaangażowanie;

- definicje oparte na przeciwieństwach: organizacja tradycyjna versus szczupła organizacja. Taką definicję kultury Lean proponuje Mann (2014: 19), zestawiając cechy kultury produkcji masowej i kultury produkcji szczupłej czy podejścia tradycyjnego i podejścia Lean Management (Walentynowicz 2013: 87).

Analiza literatury przedmiotu wskazuje, że badania nad Kulturą Lean mają charakter marginalny. Badacze i praktycy doceniają jej znaczenie, ale w swoich pracach skupiają się przede wszystkim na techniczno-organizacyjnych aspektach wdrażania koncepcji.

\section{Podejścia do badania kultury organizacyjnej w szkole wyższej}

Jak wskazują powyższe analizy, Kultura Lean jako kultura organizacyjna jest traktowana jako zjawisko wielowymiarowe, stąd wielość stosowanych podejść badawczych, definicji oraz interpretacji. W konstruowaniu teorii naukowej w badaniu kultury organizacyjnej wskazuje się na możliwość wykorzystania czterech podstawowych paradygmatów zaproponowanych przez Burella i Morgana (2005; zob. Hatch 2002: 204; Kostera 2003: 15; Sułkowski 2012: 38; Sułkowski 2016: 181). Są to:

- paradygmat funkcjonalno-systemowy (dominujący w badaniach nad kulturą organizacyjną, gdzie kultura jest zmienną zewnętrzną lub wewnętrzną, która można zarządzać i kontrolować - najważniejsi przedstawiciele: Shein, Hofstede, Handy, Cameron, Quinn). W badaniach kultury organizacyjnej szkoły wyższej wykorzystano m.in. model wartości konkurujących Camerona i Quinna (Beytekın i in. 2010). W odniesieniu do Kultury Lean można wskazać m.in. na badania Shaha i Warda w odniesieniu do przedsiębiorstw produkcyjnych (Shah i Ward 2007);

- paradygmat interpretatywno-symboliczny (kultura jest wspólnotą znaczeń charakterystyczną dla członków danej organizacji, jej składnikami są subkultury i tożsamość organizacyjna, a ona sama jest bytem amorficznym i trudnym 
do kontroli - najważniejsi przedstawiciele: Morgan, Smircich, Van Maanen, Hatch);

- paradygmat krytyczny (kultura to narzędzie sprawowania władzy organizacyjnej, opiera się na przemocy symbolicznej i indoktrynacji - najważniejsi przedstawiciele: Wilmott, Alvesson, Monin);

- paradygmat postmodernistyczny (kultura jako metafora, nierozłączna część organizacji lub część szerszej formacji kulturowej - najważniejsi przedstawiciele: Burrell, Hatch, Czarniawska).

Kostera na podstawie opracowania Smircich (1983) wskazała na dwie najważniejsze perspektywy badawcze nad kulturą organizacyjną, mając na uwadze założenia dotyczące samej kultury oraz jej roli w rzeczywistości organizacyjnej (Kostera 2003: 31). Są to:

- pespektywa nowoczesna (kultura jest tutaj definiowana jako zmienna niezależna powiązana z kulturą narodową oraz jako zmienna wewnętrzna mająca wpływ na efektywność organizacji - kultura organizacyjna jest instrumentem zarządzania, zachodzi instrumentalizacja kultury organizacyjnej);

- perspektywa interpretatywna (kultura jest tutaj definiowana jako metafora rdzenna i badana jako forma ludzkiej ekspresji w organizacji, kultura jest epistemologiczną metaforą organizacji, organizacja jest kulturą). Wielość postaw epistemologicznych stosowanych do badania kultury organizacyjnej generuje brak jednoznaczności definicji, metod badania i modeli.

Podejmując się badania Kultury Lean jako kultury organizacyjnej, w pierwszej kolejności należy zatem określić postawę badawczą (paradygmat) oraz skonstruować lub przyjąć definicję kultury organizacyjnej, co w konsekwencji przełoży się na stosowane modele i metody badawcze (Sułkowski 2012: 51). Trzeba mieć jednak na uwadze fakt, że wszelkie próby podziałów według z góry ustalonych kryteriów często mają charakter sztuczny, co ma na celu jedynie uporządkowanie wycinka rzeczywistości organizacyjnej z uwagi na chęć jej lepszego poznania i zrozumienia. Dlatego w badaniach nad kulturą organizacyjną często stosuje się kilka podejść poznawczych, najczęściej jest to paradygmat funkcjonalno-systemowy oraz interpretatywno-symboliczny. Wyniki analizy literatury przedmiotu wskazują, że podejmowane są próby badania kultury organizacyjnej szkół wyższych, przy czym dominuje w tym przypadku paradygmat funkcjonalistyczny. Do tej pory nie diagnozowano Kultury Lean Management w szkołach wyższych, co stało się przesłanką do podjęcia takich badań. Celem tych ostatnich była identyfikacja cech kultury organizacyjnej szkół wyższych w kontekście wdrażania koncepcji LM oraz określenie zakresu niezbędnych zmian. W badaniach zastosowano metody badań ankietowych oraz wywiadów. 


\section{Metodyka badań}

W badaniach ankietowych przyjęto paradygmat funkcjonalistyczny. Autorka na potrzeby badania wykorzystała model wymiarów Kultury Lean opisane w książce The Toyota Way autorstwa Likerta (2005), adoptując je do specyfiki szkól wyższych (w kwestionariuszu badawczym zrezygnowano z tych twierdzeń, które nie mają zastosowania w takich szkołach). Zakres przedmiotowy badania objął cztery wymiary Kultury Lean: Dalekosiężną koncepcję, Proces (eliminowanie marnotrawstwa), Ludzi i partnerów oraz Rozwiązywanie problemów.

Problem badawczy sformułowano następująco: czy obecna kultura organizacyjna jest barierą dla wdrażania koncepcji LM w polskich szkołach wyższych? Hipoteza badawcza brzmi: kultura organizacyjna szkół wyższych nie jest spójna z wymaganiami stawianymi Kulturze Lean i może stanowić poważną barierę w procesie zmian organizacyjnych. Postawiono również hipotezy szczegółowe: kultura organizacyjna szkół, które wdrożyły system zarządzania jakością zgodny z wymaganiami normy ISO 9001 jest bliższa wymaganiom Kultury Lean, istnieje istotna statystycznie różnica w postrzeganiu kultury organizacyjnej pomiędzy pracownikami administracyjnymi oraz naukowo-badawczymi (istnieją dwie subkultury w szkole). Badania przeprowadzono wśród pracowników 5 szkół wyższych południowej Polski z wykorzystaniem ankiety internetowej oraz tradycyjnej ankiety rozdawanej. W badaniu wzięło udział 201 osób. Oto struktura badanych ze względu na:

- zajmowane stanowisko pracy: 63\% pracownicy dydaktyczni (127 osób), 37\% pracownicy administracyjni (73 osoby);

- funkcję pełnioną w organizacji: $17 \%$ to przełożeni (34 osoby), $83 \%$ to podwładni (167 osób);

- płeć: 60\% to kobiety (119 osób), 40\% to mężczyźni (80 osób);

- staż pracy w danej szkole: 1 do 5 lat $-17 \%$ badanych, 5 do 15 lat - 50\% badanych, powyżej 15 lat - 33\% badanych.

Badania przeprowadzono między 23 maja a 30 czerwca 2016 roku. W pierwszej kolejności doszło do testowania narzędzia badawczego. Wyniki badania rzetelności z wykorzystaniem standaryzowanych współczynników alfa sugerują, że stworzony kwestionariusz pozwala przede wszystkim na jednowymiarową identyfikację typu kultury organizacyjnej, czyli jest rzetelnym narzędziem badawczym.

\section{Wyniki badań}

Wyniki badania zostały zaprezentowane z wykorzystaniem wykresu radarowego (kolejne wierzchołki wskazują na wartość oceny w odniesieniu do konkretnego numeru 
pytania, skala oceny zastosowana w badaniu to $1-5$, gdzie 1 oznacza nie, 2 - raczej nie, 3 - trudno określić, 4 - raczej tak, 5 - tak). Na wykresie przedstawiono wyniki dla wszystkich badanych szkół wyższych. Szkoły publiczne oznaczone są symbolami SP1-SP4, szkoła niepubliczna oznaczona jest symbolem SN.

Wymiar 1. Dalekosiężna koncepcja obejmowała następujące pytania:

1. Czy w uczelni istnieje jedna podzielana przez wszystkich pracowników wizja rozwoju i doskonalenia organizacji?

2. Czy pracownicy wiedzą, w jaki sposób działania podejmowane w uczelni są powiązane z sformułowaną wizją, misją i strategią działania?

3. Czy pracownicy w uczelni są zintegrowani wokół jej misji i celów, mają poczucie lojalności?

4. Czy istnieje w uczelni silne poczucie odpowiedzialności za swoje działania wśród liderów, pracowników, studentów, absolwentów i pozostałych partnerów?

5. Czy poświęca się krótkoterminowe korzyści na rzecz realizacji dalekosiężnej koncepcji rozwoju uczelni?

Wykres 1 Średnia ocena w wymiarze Dalekosiężna koncepcja

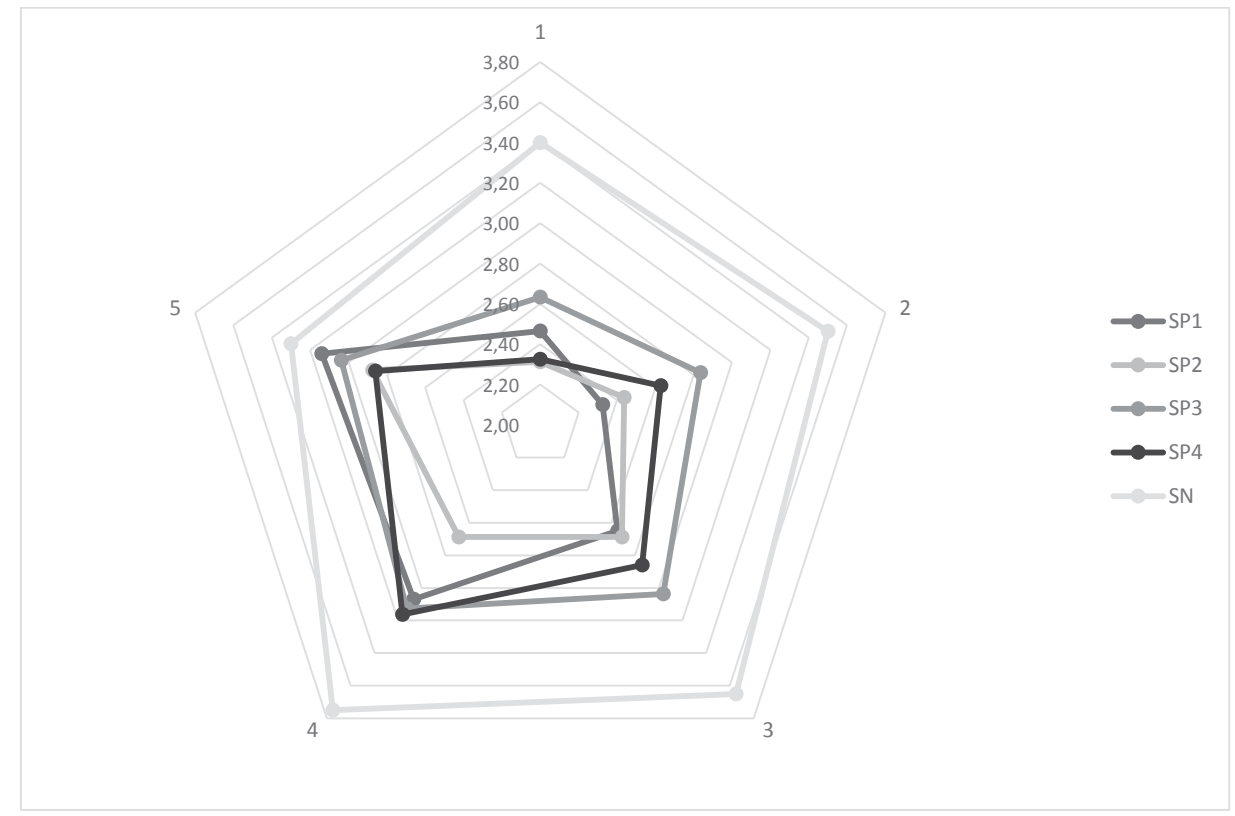

Źródło: opracowanie własne.

Wyniki badań wskazują, że pracownicy często nie znają misji, wizji i strategii rozwoju szkoły, nie biorą udziału w jej tworzeniu, często ma ona charakter fasadowy 
i nie wynika z rzetelnej analizy wewnętrznego i zewnętrznego kontekstu działania uczelni. Pracownicy nie rozumieją związków pomiędzy podejmowanymi działania a długoterminową wizją rozwoju. Można wysnuć wniosek, że tradycja i rutyna w działaniu są dominującymi elementami kultury organizacyjnej, które wyznaczają kierunki rozwoju. Potwierdzają to również wypowiedzi respondentów uzyskane w drodze wywiadów przytoczone w Dyskusji. Lepsze oceny uzyskała szkoła niepubliczna.

Wymiar 2. Proces (eliminowanie marnotrawstwa) obejmował następujące pytania:

6. Czy w uczelni identyfikuje się na bieżąco źródła marnotrawstwa i podejmuje działania naprawcze?

7. Czy standardy, procedury i inne dokumenty jasno opisują wszystkie elementy i sposób realizacji procesów?

8. Czy w uczelni podejmuje się działania mające na celu zrównoważenie procesów i niedopuszczanie do nadmiernego przeciążenia pracą ludzi i urządzeń?

9. Czy jakość jest priorytetem we wszystkich działaniach?

10. Jeśli zostaną wykryte błędy, czy procesy i działania są natychmiast przerywane?

11. Czy pracownicy przekazują swoją wiedzę o procesach i działaniach poprzez spisywanie jej w procedurach i innych dokumentach?

12. Czy w uczelni stosuje się tablice, rysunki, zestawienia i inne formy wizualizacji, aby wspierać realizację procesów i działań?

13. Czy uczelnia stosuje tylko niezawodną i sprawdzoną technologię oraz rozwiązania techniczne (np. systemy informatyczne)?

14. Czy system komunikowania jest odformalizowany, szybki i efektywny?

15. Czy sprawozdawczość jest zredukowana do niezbędnego minimum?

16. Czy otrzymywane informacje są bezbłędne?

Odpowiedzi na pytania zawarte w Wymiarze Proces ujawniają podstawowe źródła marnotrawstwa w badanych uczelniach. Są to: biurokracja i nadmiernie rozbudowana sprawozdawczość oraz brak zrównoważenia procesów (związany z ich sezonowym charakterem i presją odbiorcy - studenta, nauczycieli, kadry zarządzającej itd.). W uczelniach w znikomym stopniu są podejmowane działania mające na celu eliminację źródeł marnotrawstwa. Z obserwacji autorki wynika, że pracownicy doskonale identyfikują problemy w procesach, ale brakuje wsparcia i narzędzi ich eliminowania (np. systemu zbierania sugestii pracowniczych, szkoleń z zakresu metodyk restrukturyzacji i wprowadzania zmian np. Lean Management), ich działania nie mają charakteru systemowego i kompleksowego (zmiany w jednym procesie nie są kontynuowane w innych procesach). W uczelniach nie traktuje się dokumentacji procesowej jako elementu systemu zarządzania wiedzą, a szczególnie jako formy 
jej gromadzenia i stosowania. Rzadko wykorzystuje się różne formy zarządzania wizualnego (np. rysunki, tablice, schematy itd.). Lepsze wyniki oceny uzyskała badana szkoła niepubliczna, najprawdopodobniej z uwagi na fakt, że posiada wdrożony i certyfikowany system zarzadzania jakością zgodny z wymaganiami Normy ISO 9001 (znormalizowany system zarządzania jakością jest oparty na podejściu procesowym).

Wykres 2 - Średnia ocena w wymiarze Proces

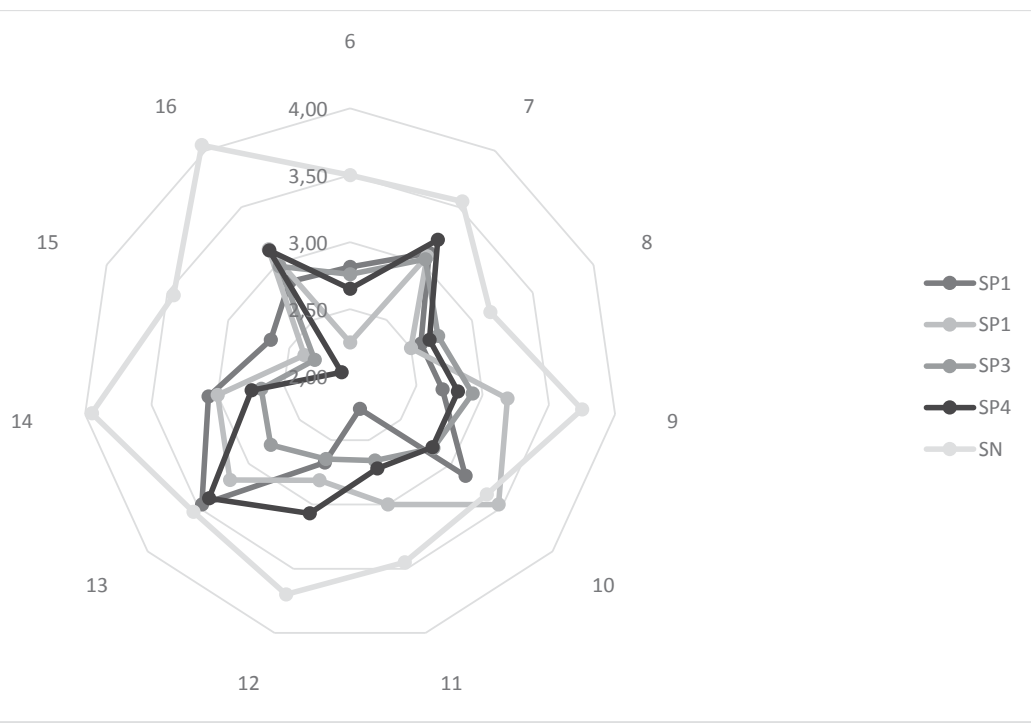

Źródło: opracowanie własne.

Wymiar 3. Ludzie i partnerzy obejmował następujące pytania:

17. Czy przełożeni i liderzy są wzorcami osobowościowymi poprzez głębokie zaangażowanie w realizację wizji i strategii uczelni?

18. Czy przełożeni umiejętnie kojarzą interesy uczelni oraz swoich podwładnych?

19. Czy relacje z przełożonym mają charakter otwarty, partnerski, odformalizowany, oparte są na zaufaniu i autorytecie?

20. Czy pracownicy poprzez szkolenia są przygotowywani do świadomego i czynnego uczestnictwa w zmianach?

21. Czy uczelnia jest otwarta na zmiany techniczne, organizacyjne oraz społeczne, a zmiana jest traktowana jako szansa i wyzwanie?

22. Czy w uczelni każda zmiana jest otwarcie dyskutowana w celu ewentualnej korekty planów, istnieje kultura „odmiennych zdań”? 
23. Czy cele całej uczelni są ważniejsze niż cele indywidualne lub określonych grup? 24. Czy uczelnia szanuje swoich partnerów i dostawców, traktując ich jako rozszerzenie własnej organizacji?

25. Czy obecna kultura organizacyjna uczelni zawiera akceptowane przez wszystkich zasady i wartości?

Wykres 3 - Średnia ocena w wymiarze Ludzie i partnerzy

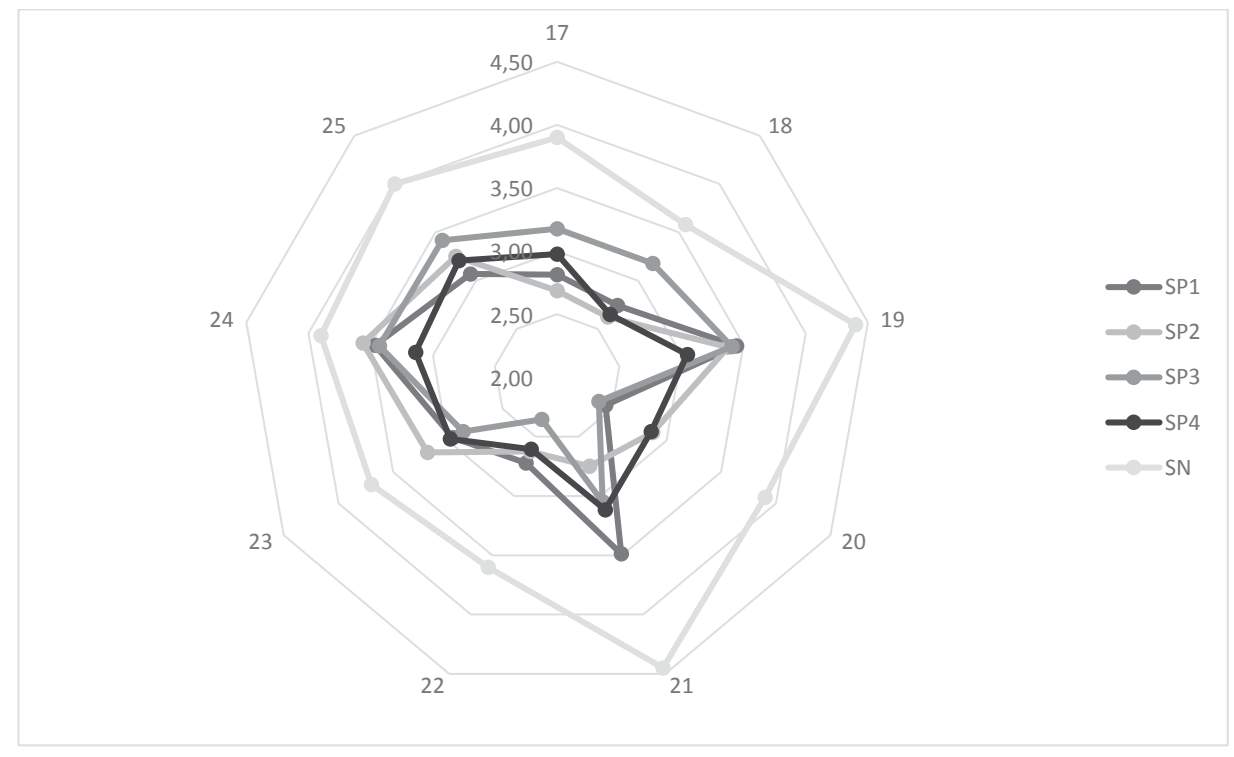

Źródło: opracowanie własne.

Kolejne wyniki badania w Wymiarze Ludzie i Partnerzy wskazują na specyficzne cechy kultury organizacyjnej w badanych szkołach, które nie sprzyjają wdrażaniu koncepcji Lean Management. Dotyczy to przede wszystkim nieumiejętnego kojarzenia przez przełożonych interesów uczelni i pracowników, co skutkuje m.in. tworzeniem się w szkołach subkultur organizacyjnych. Wyniki przeprowadzonej analizy statystycznej wskazują, że w badanych szkołach wytworzyły się dwie subkultury: podwładnych i przełożonych, przy czym przełożeni zdecydowanie wyżej oceniali badane aspekty. Może być to uwarunkowane m.in. nieefektywnymi systemami informacyjnymi i sformalizowanym systemem komunikacji (co potwierdzają wyniki badań w poprzednim wymiarze). Pracownicy oceniają, że nie są odpowiednio przygotowani do świadomego i czynnego uczestnictwa w zmianach oraz nie są one poprzedzone otwartą dyskusją. Istnieje silna hierarchia oraz nie podważa się zdania przełożonego czy pracownika o wyższym 
statusie w hierarchii. Liderzy i przełożeni nie są dla większości badanych wzorcami osobowościowymi poprzez swoje zaangażowanie w realizację strategii uczelni. Ważnym pozytywnym elementem kultury organizacyjnej jest szacunek dla partnerów i dostawców oraz otwartość na zmiany. W opinii badanych obecna kultura organizacyjna jest w zasadzie akceptowana przez pracowników w zakresie wartości i zasad.

Wymiar 4. Rozwiązywanie problemów obejmowal następujące pytania:

26. Czy pracownicy są oceniani całościowo za wyniki swoich działań (nie ocenia się za incydenty)?

27. Czy pracownicy są włączeni w ocenę swoich działań?

28. Czy problemy są rozwiązywane w międzyfunkcjonalnych/interdyscyplinarnych zespołach?

29. Czy pracownicy identyfikują na bieżąco problemy i sposoby ich rozwiązywania?

30. Czy pracownicy mają wysoką samoocenę swoich kompetencji i chcą rozwiązywać problemy (nie ma miejsca postawa „wyuczonej nieudolności”)?

31. Czy liderzy i przełożeni są osobiście zaangażowani w rozwiązywanie problemów w miejscu ich powstawania (nie są to decyzje „zza biurka”)?

32. Czy rozwiązanie problemu poprzedza gruntowna jego analiza (kompleksowa analiza danych i faktów)?

33. Czy wszyscy pracownicy uczestniczą w ciągłym doskonaleniu organizacji (niezależnie od stanowiska)?

34. Czy problemy są rozwiązywanie na zasadzie uzyskania porozumienia pomiędzy zainteresowanymi stronami?

35. Czy wyniki audytów, kontroli i sprawdzania działań oraz procesów są wykorzystywane do ich nieustannego doskonalenia (a nie do szukania winnego)?

36. Czy uczelnia uczy się na swoich błędach?

Wykres 4 prezentuje wyniki oceny w Wymiarze Rozwiązywania problemów. Należy zwrócić uwagę na fakt, że w badanych uczelniach brakuje systemowego i kompleksowego podejścia do rozwiązywania problemów. Pracownicy nie czują się odpowiedzialni za doskonalenie organizacji. Przy czym wysoko oceniają swoje kompetencje i chcą rozwiązywać problemy w realizowanych procesach. Można zatem stwierdzić, że istnieje potencjał kreatywności oraz zaangażowania w proces doskonalenia, który może być umiejętnie wykorzystany w restrukturyzacji uczelni. Potwierdzają to też wypowiedzi uzyskane $\mathrm{w}$ wywiadach zaprezentowanych w Dyskusji. 
Wykres 4 - Średnia ocena w wymiarze Rozwiązywanie problemów

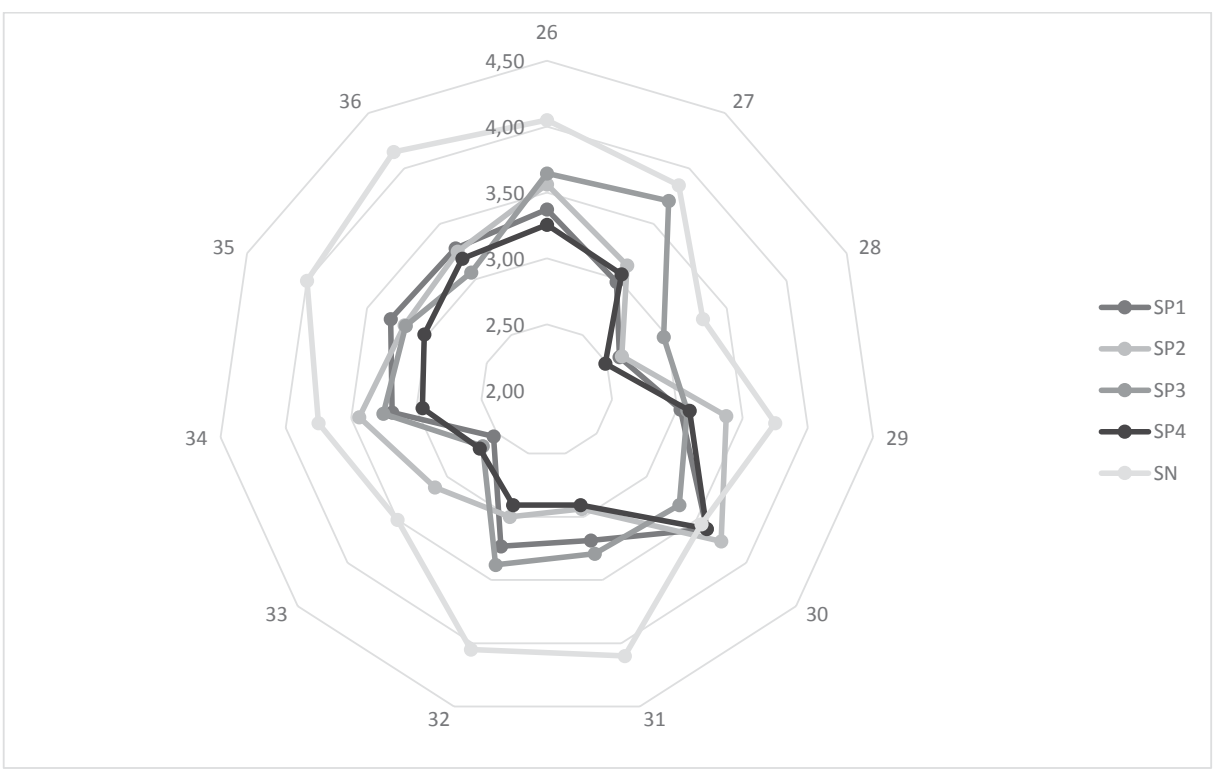

Źródło: opracowanie własne.

Wykres 5 przedstawia zestawienie średnich ocen badanych wymiarów Kultury Lean.

Zaprezentowane wyniki badań potwierdzają postawioną hipotezę, że kultura organizacyjna badanych szkół stanowi barierę we wdrażaniu zmiany polegającej na restrukturyzacji procesowej zgodnej z zasadami Lean Management. W badaniach zbadano różnice w ocenie poszczególnych wymiarów Kultury Lean pomiędzy szkołami oraz zależność pomiędzy wymiarami kultury organizacyjnej a informacjami zawartymi w metryczce (rodzaj szkoły, stanowisko, funkcja w organizacji, płeć, staż pracy, posiadanie przez szkołę ISO 9001). W celu oceny różnic w poszczególnych wymiarach kultury pomiędzy różnymi typami szkół lub respondentów wyznaczano średnie wartości miar w odpowiednich grupach. Do badania czy zaobserwowane różnice w poziomach przeciętnych są istotne statystycznie, stosowano test t Studenta z niezależną estymacją wariancji. W przypadku gdy porównywano trzy grupy, wykorzystano nieparametryczny test Kruskala-Wallisa. Poniżej przedstawiono najważniejsze wnioski z badań:

- na ocenę kultury Lean istotny statycznie wpływ ma rodzaj szkoły. Wyniki badania wskazują, że kultura organizacyjna szkoły niepublicznej jest bliższa kulturze Lean (wyższa średnia ocena badanych wymiarów kultury). Z uwagi na fakt, że badania miały charakter pilotażowy trudno jest jednoznacznie zinterpretować wynik takiego badania; 
Wykres 5 - Średnia wymiarów Kultury Lean w badanych szkołach

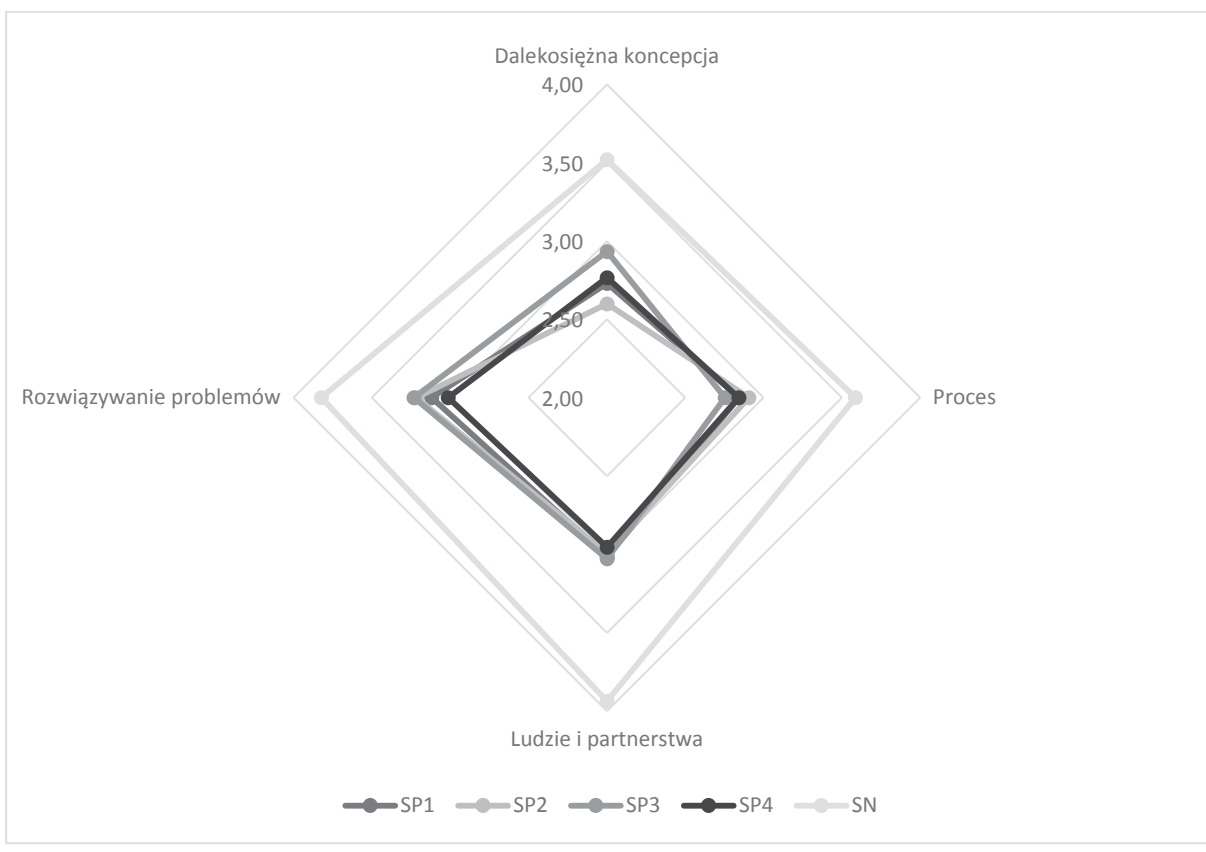

Źródło: opracowanie własne

- posiadanie certyfikatu ISO ma wpływ na ocenę wymiarów kultury Lean, czyli proces i ludzie. W badaniu wzięły udział dwie szkoły, które posiadały taki certyfikat, dlatego można z pewnym prawdopodobieństwem przypuszczać, że taka zależność istnieje w odniesieniu do pozostałych szkół wyższych w Polsce;

- zajmowane stanowisko (administracyjne, naukowe) nie ma wpływu na ocenę wymiarów Kultury Lean (hipoteza o subkulturach nie została potwierdzona);

- funkcja w organizacji (podwładny, przełożony) ma istotny statystycznie wpływ na ocenę wymiarów Kultury Lean, przy czym jest to mocno zróżnicowane w zależności od badanej szkoły. Przełożeni wyżej ocenianą badane wymiary. Można zatem wnioskować, że w badanych szkołach wyłaniają się dwie subkultury: przełożonych i podwładnych;

- płeć pracownika nie ma wpływu na ocenę kultury Lean, wyjątkiem jest wymiar Proces;

- staż pracy pracownika nie ma wpływu na ocenę kultury Lean, wyjątek stanowi wymiar Ludzie. Pracownicy młodsi stażem (do 5 lat) wyżej oceniają wymiary kultury Lean. 
W wyniku przeprowadzonej analizy regresji można stwierdzić, że uzyskane wyniki wskazują, że zmiennymi, które w istotny sposób różnicują wyniki ankiety, są: rodzaj szkoły (publiczne mają dużo niższe wyniki oceny), funkcja (podwładni uzyskiwali niższe wyniki oceny), posiadanie certyfikatu ISO oraz staż pracy (osoby ze stażem powyżej 5 lat uzyskiwały wyższe wyniki oceny).

Przeprowadzone badania mają charakter pilotażowy, jednak ich wyniki znajdują potwierdzenie $\mathrm{w}$ wywiadach przeprowadzonych z pracownikami uczestniczącymi w projekcie restrukturyzacji realizowanym z wykorzystaniem metodyki Lean. Wyniki zostaną omówione i przedstawione w kolejnej części opracowania.

\section{Dyskusja}

Wyniki przeprowadzonych badań pilotażowych potwierdzają postawioną na wstępie hipotezę, że kultura organizacyjna badanych szkół wyższych nie sprzyja wdrażaniu koncepcji Lean Management. Pojawia się tutaj jednak szereg poważnych wątpliwości, które jednocześnie stanowią podstawowe ograniczenia przeprowadzonego badania oraz jawią się jako nowe wyzwania badawcze w obszarze zarządzania kulturą organizacyjną w szkołach wyższych.

Pierwsze ograniczenie to paradygmat badawczy, jaki został przyjęty w badaniu. Jak już wcześniej podkreślono, dominującym podejściem w badaniach kultury Lean jest podejście funkcjonalistyczne. Wynika to przede wszystkim z faktu, że koncepcja Lean Management narodziła się i była rozwijana w środowisku biznesu i przedsiębiorstw produkcyjnych. W badaniu wykorzystano kwestionariusz badawczy oparty na zasadach Lean opisanych przez Likera w książce The Toyota Way. W paradygmacie funkcjonalistycznym (Kostera 2003: 16), opartym na powierzchownych, „produkcyjnych” miarach, niemożliwe jest pełne zrozumienie istoty i dojrzałości uczelni do wdrażania Lean Management. Podejście obiektywistyczne powoduje, że kulturą organizacyjną badacze zajmują się z zewnątrz, podobnie jak czynią to przedstawiciele nauk przyrodniczych (Hatch 2001: 221). Do tej pory nie były podejmowane badania, które pokazywałyby, w jaki sposób koncepcje produkcyjne, tj. Lean Management wdrażane w organizacjach edukacyjnych i publicznych, zmieniają swoje definicje, znaczenia i sposoby rozumienia oraz realizacji. Czy zmiany kultury organizacyjnej dotykają istotnych wartości, na jakich oparta jest szkoła wyższa, czy, jak twierdzi Hosftede, zmiany następują tyko na poziomie praktyk (zgodnie z tzw. diagramem cebuli dotyczą one zewnętrznych warstw, czyli rytuałów, bohaterów, symboli) (Hofstede i in. 2011: 33)? Dlatego postuluje się rozszerzenie perspektywy badawczej o podejście humanistyczne oparte na paradygmacie interpretatywnym (Hatch 2001; Kostera 2003; Alvesson 2009; Czarniawska 2010; Sułkowski 2012). 
Drugie ograniczenie, na jakie można wskazać, wynika z doświadczeń własnych autorki w pracy oraz obserwacji prac nad projektami restrukturyzacyjnymi prowadzonymi z wykorzystaniem narzędzi Lean Management. Dotyczy ono sposobu oraz kolejności wprowadzanych zmian. Trwa dyskusja nad tym, w jakiej kolejności należy wprowadzać zmiany w szkołach wyższych. Czy zmiany techniczno-organizacyjne powinny poprzedzać zmiany społeczne gdyż, często poprzez odgórne (nakazowe) włączenie pracowników i kierowników wymuszają/inspirują pożądane zmiany w kulturze organizacyjnej szkoły w kierunku Kultury Lean? Czy też w pierwszej kolejności należy pracować nad kulturą organizacyjną i przygotować pracowników do zmiany, tak aby ułatwić przeprowadzenie restrukturyzacji oraz zapewnić trwałość jej efektów? Wyniki badania wskazują, że szkoły, które wdrożyły system zarządzania jakością zgodny z wymaganiami Normy ISO mają wyższe wyniki w Wymiarze Ludzie i partnerstwo. Normy ISO są odczytywane przez środowisko akademickie jako koncepcje produkcyjne i biznesowe, które zagrażają zasadom i tradycji akademickiej. Taki ich odbiór wynika przede wszystkim z nieprawidłowego sposobu wdrażania „z góry do dołu” (up to down), który wymusza zmiany głównie w sferze techniczno-organizacyjnej. Warunkiem trwałości zmian oraz budowania kultury nieustannego doskonalenia (continous improvement) jest zastosowanie podejścia „z dołu do góry” (bottom - up), w którym wykorzystuje się naturalną inicjatywność, kreatywność i zaangażowanie pracowników. Jest to podejście typowe dla Lean Management.

Wywiady przeprowadzone z uczestnikami projektu prowadzonego na Wydziale Zarządzania i Komunikacji Społecznej UJ w Krakowie potwierdzają, że zmiana kultury organizacyjnej, a szczególnie postaw pracowników następuje wraz z poznawaniem i stosowaniem metod i technik Lean Management ${ }^{2}$. W trakcie wywiadu zadano pytania na temat znajomości metodyki Lean, jej zalet i wad oraz możliwości wykorzystania w szkole wyższej, jak również wpływu projektu na postawę w rozwiązywaniu problemów organizacyjnych ${ }^{3}$. Poniżej zamieszczono

2 Projekt został zrealizowany w okresie październik-grudzień 2017 roku. Celem zrealizowanego projektu była restrukturyzacja procesu związanego z prowadzeniem przewodów doktorskich (wszczynanie i zamykanie przewodu). Jest to proces ważny dla Wydziału, niezwykle skomplikowany, rozciągnięty w czasie oraz silnie uwarunkowany przepisami prawa. Głównymi wskaźnikiem jakości procesu jest zgodność z przepisami prawa (terminy oraz wymagania formalne). W projekcie wykorzystano techniki i narzędzia tj. mapowanie strumienia wartości (Value Stream Mapping), SIPOC, standardową procedurę operacyjną (SOP Standard Operating Procedure). Obecnie trwają prace nad opracowaniem nowej dokumentacji procesowej (procedur, instrukcji i innych dokumentów). W grupie projektowej pracowało pięć osób.

3 W wywiadzie zadano następujące pytania: Czy przed rozpoczęciem projektu coś Pani/Pan wiedział na temat LM? Jaka była Pani/Pana postawa, co Pani/Pan myślał(a), co czuł(a), kiedy dowiedziała się, że projekt będzie realizowany zgodnie z metodyką LM? Czy realizacja tego projektu zmieniła Pani/ Pana postawę w pracy wobec rozwiązywania różnych problemów? Jeśli tak, to w jaki sposób? Pani/ 
wybrane wypowiedzi pracowników, które wskazują na zmiany, jakie są skutkiem realizowanego projektu ${ }^{4}$.

Pracownicy przed rozpoczęciem projektu nie znali zasad i metodyki Lean Management, niektórzy prezentowali sceptyczne podejście w tym zakresie. Świadczy o tym odpowiedź na pytanie o postawę przed rozpoczęciem projektu: „[...] Raczej nie spodziewałam się rewolucji. Pomyślałam, że warto posłuchać teorii, może coś uda się wykorzystać w praktyce". Po zrealizowanym projekcie postawy uległy zmianie potwierdzają to poniższe wypowiedzi:

Uważam, że LM porządkuje pewne działania i czynności, wskazuje, co jest zbędne, czego nam brakuje i co należy jeszcze poprawić. Przygotowywane procedury i wytyczne umożliwią większą elastyczność w wykonywaniu pracy na różnych stanowiskach m.in. pomoże przy zastępowaniu się pracowników, zatrudnianemu pracownikowi ułatwi wdrażanie się do pracy i zapoznanie z czynnościami w nowym miejscu.

Analiza poszczególnych procesów pozwala m.in. na bardziej efektywne wykorzystanie czasu pracy poprzez np. jego skrócenie oraz unikanie błędów i większą mobilność pracowników na stanowiskach pracy.

Analiza procesu „przewodów doktorskich” wyżej wymienioną metodą wskazała, jak ważną rzeczą jest monitorowanie procesów realizowanych w pracy (szereg czynności realizujemy na podstawie „bo tak było ustalone”). Jak ważne jest, aby nie mnożyć dokumentów, które nie są niezbędne w danym procesie.

Respondenci wskazali również, w jaki sposób realizacja projektu wpłynęła na relacje w grupie:

Wspólna praca integruje zespół i pozwala uczestniczyć w opracowywaniu rozwiązań i wdrażaniu pomysłów wszystkim członkom zespołu.

Relacje ze współpracownikami nie uległy zmianie, wyżej wymieniona koncepcja wskazała na konieczność większej komunikacji pomiędzy osobami, które biorą udział w danym procesie.

Pana zdaniem, jakie mogą wystąpić bariery i źródła oporu wobec LM? Jakie są Pani /Pana zdaniem korzyści z zastosowania metody LM w analizie procesu? Jak Pani /Pan ocenia swój udział w tym projekcie (w aspekcie indywidualnych korzyści i kosztów). Czy Lean jest dobrą metodą wdrażania zmian w UJ, dlaczego tak, dlaczego nie? Czy Pani/Pana zachowania i sposób kształtowania relacji z kolegami w pracy się zmienił na wskutek wdrażania koncepcji Lean? W jaki sposób? W jaki sposób powinny być wspierane osoby i zespoły wdrażające LM w szkołach wyższych?

4 Badane osoby wyrazily zgodę na anonimowe zacytowanie ich wypowiedzi w publikacji. 
Wdrażanie wyżej wymienionej metody wymaga bardzo dużo czasu i współpracy zespołu, którego dany proces dotyczy. Kluczowym elementem jest chęć zmiany i komunikacja.

Ważnym aspektem zmiany postaw było uświadomienie barier restrukturyzacji procesowej. Takie doświadczenia umożliwią w przyszłości lepiej zaplanować prace nad projektami Lean zarówno z punktu widzenia organizacji czasu pracowników, jak i roli kierownictwa. Poniżej zaprezentowano wybrane wypowiedzi na temat barier wdrażania Lean:

Ograniczenia czasowe oraz mnogość bieżących spraw w dziekanacie nie pozwala skupić się na wnikliwej analizie i skutecznej poprawie jakości procesów.

Niechęć niektórych pracowników do jakichkolwiek zmian.

Specyficzne środowisko uczelni wyższej, panujące od lat te same zasady, konserwatyzm w myśleniu, nadmiernie rozbudowane procedury, ucieczka przed odpowiedzialnością.

Wykorzystanie metody LM jest procesem długotrwałym i wymaga dużej wiedzy na temat danego procesu. Czas, jaki należy poświęcić analizie danego procesu metodą LM, może być źródłem oporu.

Jako czynnik sukcesu wskazano: „[p]oparcie władz oraz stanowcze egzekwowanie przyjętych rozwiązań”. Na pytanie o korzyści odniesione z udziału w projekcie wskazano:

Korzyści pod kątem poszerzenia swojej wiedzy z zakresu zarządzania, którą planuję wykorzystać w praktyce, jeśli tylko uda się to zrobić przy współpracy z innymi pracownikami.

Po szkoleniu uświadomiłam sobie, że pewne czynności i procesy można uprościć lub skrócić i w ten sposób zaoszczędzić czas. Nie jest to łatwe w miejscu, w którym pracujemy, wręcz powiedziałabym bardzo trudne, ponieważ zależy nie tylko od nas, ale np. od naszych przełożonych, osób, z którymi współpracujemy, czasu, którym dysponujemy.

Wyniki przeprowadzonych wywiadów potwierdzają, że pracownicy pracujący w projektach restrukturyzacyjnych i stosujący metodykę Lean stają się jednocześnie autorami i odbiorcami zmian, co wpływa na zwiększenie prawdopodobieństwa ich trwałości. Wyniki badania ankietowego wskazują, że taki potencjał tkwi w pracownikach badanych uczelni oraz oceniają oni swoje uczelnie jako otwarte na zmiany. Zatem zmiana techniczno-organizacyjna przebiega równolegle i jest zintegrowana 
ze zmianą społeczną, jeżeli projekty są wdrażane z przyjęciem podejścia oddolnego charakterystycznego dla Lean Management.

\section{Podsumowanie}

Przeprowadzona analiza literatury przedmiotu wskazuje, że autorzy w swoich badaniach skupiają się przede wszystkim na uwarunkowaniach oraz metodach i narzędziach Lean Management, nie rozwijając problematyki w obszarze kwestii społecznych oraz uwarunkowań kulturowych wdrażania koncepcji Lean, również w szkołach wyższych. Wyniki przeprowadzonych badań pilotażowych potwierdzają, że jest to problematyka ważna i wymagająca dalszych analiz, gdyż kultura organizacyjna badanych szkół odbiega od przyjętych w badaniu zasad określonych w Lean Management.

Do tej pory nie były podejmowane badania, które pokazywałyby, w jaki sposób koncepcje produkcyjne, tj. Lean Management wdrażane $\mathrm{w}$ organizacjach edukacyjnych i publicznych, zmieniają swoje definicje, znaczenia i sposoby rozumienia oraz realizacji oraz jak i w jakim zakresie wpływają na kulturę organizacyjną. Zaprezentowane w opracowaniu wyniki badania jednoznacznie wskazują, że zastosowanie paradygmatu funkcjonalistycznego w badaniu kultury organizacyjnej uczelni jest niewystarczające, gdyż nie pozwala dostrzec w pełni innych składników i obszarów Kultury Lean. Dlatego postuluje się rozszerzenie perspektywy badawczej o podejście humanistyczne oparte na paradygmacie interpretatywnym. Przyjęcie takiego podejścia ontologicznego pozwoli na teoretyczne wzbogacenie koncepcji Lean, pogłębienie zrozumienia jej istoty i sensu wdrażania w szkołach wyższych. Do tej pory nie podjęto badań, w których traktuje się kulturę Lean jako teoretyczną metaforę epistemologiczną uczelni. Pojawia się także potrzeba stworzenia nowych narzędzi do badania kultury Lean, jej diagnozy oraz oceny postępu we wprowadzanych zmianach, które byłyby dostosowane do specyfiki szkoły wyższej.

Należy tez zwrócić uwagę na fakt, że dostępne opracowania w zakresie Lean Higher Education napisane są na podstawie doświadczeń amerykańskich oraz modelu anglosaskiego nastawionego na kształcenie i studentów (student-centered). Nie uwzględnia europejskiej tradycji uniwersytetu kontynentalnego opartego na modelu humboldtowskim, który orientuje się na łączenie kształcenia i badań oraz na potrzeby kadry akademickiej (faculty-centered).

\section{Literatura}

Alvesson, M. (2009). At home ethnography: struggling with closeness and closure. W: S. Ybema, D. Yanow, H. Wels i F.H. Kamsteeg (red.), Organizational Ethnography: Studying the Complexity of Everyday Life (156-217). London: Sage. 
Alvesson, M. (2013), The Triumph of Emptiness: Consumption, Higher Education and Work Organization. Oxford: Oxford University Press.

Antonowicz, D. (2015). Między siłą globalnych procesów a lokalną tradycją: Polskie szkolnictwo wyższe $w$ dobie przemian. Toruń: Wydawnictwo UMK.

Balzer, K. (2010). Lean Higher Education. New York: CRP Press.

Bednarek, M. (2007). Doskonalenie systemów zarządzania: Nowa droga do przedsiębiorstwa Lean. Warszawa: Difin.

Burell, G., Morgan, G. (2005). Sociological Paradigms and Organisational Analysis: Elements of the Sociology of Corporate Life. Burlington: Ashgate Publishing.

Czarniawska, B. (2010). Trochę inna teoria organizacji: Organizowanie jako konstrukcja sieci działań. Warszawa: Poltext.

Czerska, J. (2009). Doskonalenie strumienia wartości. Warszawa: Difin.

Emiliani, B. (2005). Your Turn: Getting Lean. BizEd, maj/czerwiec.

Emiliani B. (2015). Lean University: A Guide to Renewal and Prosperity. Wethersfield, Conn.: The CLBM, LLC.

Francis, D.E., Krehbiel, T.C. i Balzer, W.K. (2017). Lean Applications in Higher Education. https://the-lmj.com/2017/03/lean-applications-in-higher-education-part-one [10.04.2018].

Hamrol, A. (2015). Strategie i praktyki sprawnego działania: Lean, Six Sigma i inne. Warszawa: Wydawnictwo Naukowe PWN.

Hatch, M. (2002). Teoria organizacji. Warszawa: Wydawnictwo Naukowe PWN.

Hofstede, G., Hofstede, G.J. i Minkov, M. (2011). Kultury i organizacje. Warszawa: Wydawnictwo Naukowe PWN.

McNay, I. (2006). Values, Principles and Integrity: Academic and Professional Standards in Higher Education. https://www.oecd.org/site/imhe2006bis/37245044.pdf [10.04.2018].

Jakubik, M., Kagan, R., Hanusyk, K. i Koch, T. (2012). Motywowanie pracowników w środowisku Lean. W: Ciagłe doskonalenie w oparciu o zasady Lean Manufacturing. Wrocław: Wyd. Lean Enterprise Institute Polska.

Jabłecka, J. (2000). Misja organizacji a misja uniwersytetu. Nauka i Szkolnictwo Wyższe. 16(2): 7-25.

Kostera, M. (2003). Antropologia organizacji: Metodologia badań terenowych. Warszawa: Wydawnictwo Naukowe PWN.

Kwiek, M. (2015). Uniwersytet $w$ dobie przemian. Warszawa: Wydawnictwo Naukowe PWN.

Kwiek, M. (2011). Filozofia - demokracja - uniwersytet: Wyzwania epoki globalizacji. W: P.W. Juchacz, K. Kozłowski i A. Cooper (red.), Filozofia a demokracja, t III. Poznań: Wydawnictwo Naukowe IFUAM.

Leja, K. (2013). Zarządzanie uczelnią: Koncepcje i wspótczesne wyzwania. Warszawa: Oficyna Wolters Kluwer business. 
Lenartowicz, M. (2016). Natura oporu: Uniwersytet jako samowytwarzajacy się system społeczny. Poznań: CSPP UAM.

Liker, J.K. i Morgan, J.M. (2006). The Toyota Way in Services: The Case of Lean Product Development. Academy Management Perspective. 20(2): 5-20

Liker, J.K. (2005). Droga Toyoty: 14 zasad zarządzania wiodacej firmy produkcyjnej świata. Warszawa: MT Biznes.

Maciąg, J. (2011). Ocena systemu zapewnienia jakości kształcenia w szkole wyższej. Katowice: Wydawnictwo AWF w Katowicach.

Maciąg, J. (2016a). Zastosowanie podejścia procesowego w zarządzaniu publicznymi szkołami wyższymi - wyzwania teorii i praktyki. Nauka i Szkolnictwo Wyższe. 47(1): 163-180.

Maciąg, J. (2016b). Uwarunkowania wdrożenia koncepcji Lean Service w polskich szkołach wyższych. Zarządzanie publiczne. 33(1): 51-64.

Mann, D. (2014). Tworzenie kultury Lean. Wrocław: ProdPublishing.

Lacatus, M.L. (2013). Organizational culture in contemporary university. Procedia - Social and Behavioral Sciences. 76: 421-425.

Geppert, M. i Hollinshead, G. (2017). Signs of dystopia and demoralization in global academia: Reflections on the precarious and destructive effects of the colonization of the Lebenswelt. Critical Perspectives on International Business. 13(2): 136-150.

Beytekın, O.F., Yalçinkava, M., Doğan, M. i Karakoç, N. (2010). The Organizational Culture at The University. The International Journal of Educational Researchers 2(1): 1-13.

Parkes, A. (2017). Kulturowe uwarunkowania Lean Management. Warszawa: Difin.

Radnor, Z., Walley, P., Stephens A. i Bucci, G. (2006). Evaluation of the Lean Approach to Business Management and Its Use in the Public Sector. Scottish Executive Social Research: Crown Copyright.

Radnor, Z. i Bucci, G. (2011). Analysis of Lean Implementation in UK Business Schools and Universities. Raport przygotowany dla Association for Business Schools, https://www. york.ac.uk/admin/po/processreview/ABS\%2oFinal\%2oReport\%2ofinal.pdf [10.04.2018].

Robinson M. i Yorkstone, S. (2014). Becoming a Lean University: The case of the University of St. Andrews. Leadership and Government in Higher Education. 1: 41-72.

Santana, S., Moreira, C., Roberto, T. i Azambuja, F. (2010). Fighting for excellence: the case of the Federal University of Pelotas. Higher Education. 60(3): 321-341

Shah, R. i Ward, P.T. (2007). Defining and developing measures of lean production. Journal of Operational Research. 25(4): 785-805.

Smircich, L. (1983). Concepts of Culture and Organizational Analysis. Administrative Science Quarterly. 28(3): 339-358.

Sulkowski, Ł. (2012). Kulturowe procesy zarządzania. Warszawa: Difin.

Sułkowski, Ł. (2016). Kultura akademicka. Koniec utopii? Warszawa: Wydawnictwo Naukowe PWN.

Sułkowski, Ł. (2017). Fuzje uczelni: Czy w szaleństwie jest metoda? Warszawa: Wydawnictwo Naukowe PWN. 
Walentynowicz, P. (2013). Uwarunkowania skuteczności wdrażania Lean Management $w$ przedsiębiorstwach produkcyjnych $w$ Polsce. Gdańsk: Wydawnictwo UG.

Wolniak, R. (2012). Wymiary kulturowe polskich organizacji z doskonalenie zarzadzania jakością. Warszawa: CeDeWu.pl.

Woźnicki, J. (2000). Dylematy modelowe w kształtowaniu systemu szkolnictwa wyższego u progu XXI wieku. Nauka. 4.

Yorkstone, S. (2016). Lean Universities. W: T. Netland i D. Powell (red.), The Routledge Companion to Lean Management. Abingdon: Routledge.

\section{Lean Culture in the Polish Universities (results of a preliminary research)}

SUMMARY: If the process-based approach is not directly connected with changes in organizational culture, it minimizes benefits of restructuring the school and does not contribute to process improvement in the long term. The paper presents a preliminary results of the research which purpose was to identify the common characteristics of Lean Culture in HEIs and to evaluate a range of changes in organizational culture with respect to LM implementation. In research author used the methods of literature analysis, questionnaires (based on the dimensions of Lean Culture formulated in the Likert's book “The Toyota Way"), interviews and own experience. The general hypothesis formulated in the research was confirmed - the organizational culture of investigated universities hinders the implementation of LM. The assessment of Lean Culture is statistically influenced by the type of school, function in organisation and seniority. The results of interviews showed that the critical condition of successful change of organisational culture in a university is adoption of the bottom - up approach. This approach allows to integrate the changes in organisational and technical system and social system in an organisation. The results of research also indicate that the usage of a functionalist paradigm doesn't allow to take into consideration all dimensions of Lean Culture. Therefore, researchers have been calling for the broadening of the research perspective with a humanistic approach based on the interpretative paradigm.

KEYWORDS: organisational culture, lean management culture, university, evaluation of lean culture

CYTOWANIE: Maciąg, J. (2018). Kultura Lean Management w polskich szkołach wyższych (wyniki badań pilotażowych). Nauka i Szkolnictwo Wyższe. 1(51): 69-95. DOI: 10.14746/nisw.2018.1.3.

JUSTYNA MACIĄG - dr nauk ekonomicznych w zakresie nauk o zarządzaniu, adiunkt w katedrze Zarządzania Publicznego w Instytucie Spraw Publicznych na Wydziale Zarządzania i Komunikacji Społecznej Uniwersytetu Jagiellońskiego w Krakowie. Jej główne zainteresowania badawcze dotyczą współczesnych koncepcji i metod zarządzania w organizacjach publicznych i biznesowych, ze szczególnym uwzględnieniem szkół wyższych. Publikacje oraz prace badawcze w obszarze szkolnictwa wyższego autorki obejmują problematykę doskonalenia jakości usług, pomiaru i oceny skuteczności 
i efektywności systemu zarządzania jakością, metod współpracy z otoczeniem, a także restrukturyzacji szkół wyższych poprzez zastosowanie koncepcji i metod podejścia procesowego (zarządzania jakością, Lean Management). W latach 2007-2012 pełniła funkcję Pełnomocnika Rektora ds. Jakości Kształcenia i Akredytacji na Akademii Wychowania Fizycznego w Katowicach. Posiada również międzynarodowe uprawnienia Pełnomocnika Systemu Zarządzania Jakością, Audytora wewnętrznego oraz Certyfikat PRINCE2® Foundation Examination. Ukończyła studia podyplomowe „Lean services” na Uniwersytecie Ekonomicznym we Wrocławiu oraz szkolenie z zakresie Green Belt. Obecnie jest członkiem komitetu sterującego międzynarodowej sieci Lean HE oraz Zespołu ds. odbiurokratyzowania procedur w Uniwersytecie Jagiellońskim w Krakowie. 